\title{
ETNOSENTRISME DALAM TENGGELAMNYA KAPAL VAN DER WIJCK KARYA HAMKA DALAM PERSPEKTIF STRUKTURASI GIDDENS
}

\author{
Uci Elly Kholidah \\ Siti Hardiyanti Amri \\ Alumni S2 Ilmu Sastra, Fakultas Ilmu Budaya Universitas Gadjah Mada \\ Email: sitihardiyanti0791@gmail.com, ellyuci@gmail.com
}

\begin{abstract}
Abstrak
Sebagai makhluk sosial, manusia saling berinteraksi dengan gugus pengetahuan dan pengalaman berbeda satu sama lain. Penelitian ini bertujuan untuk menganalisis etnosentrisme dalam novel Tenggelamnya Kapal Van der Wijck karya Hamka dengan perspektif Strukturasi Giddens. Strukturasi menolak pandangan dualisme dengan menekankan dualitas agen dan struktur. Setiap agen bertindak berdasarkan skemata atau struktur dalam ruang dan waktu tertentu. Selanjutnya, aktivitas sosial para agen tersebut memengaruhi struktur itu kembali. Dalam konteks sastra, agen merujuk pada penulis dan tokoh-tokoh yang ada di dalam karya sastra. Hasil penelitian ini menunjukkan bahwa gejala etnosentrisme melalui tindakan para tokoh dalam novel merupakan manifestasi struktur penulis. Novel Tenggelamnya Kapal Van der Wijck merupakan sarana komunikasi Hamka selaku agen yang dimotivasi oleh keinginan akan perbaikan dan perubahan terhadap struktur budaya Minangkabau. Karya ini juga mampu mengubah sistem sosial yang membentuk struktur etnosentrisme Hamka.
\end{abstract}

Kata Kunci: strukturasi; agen; struktur; Anthony Giddens; Tenggelamnya Kapal Van der Wijck

\begin{abstract}
As social beings, humans interact using a distinct set of knowledge and experiences. This research aims to analyze ethnocentrism in the novel Tenggelamnya Kapal Van der Wijck by Hamka through the perspective of Giddens' structuration. The theory of structuration rejects the notion of dualism by highlighting the duality of agent and structure. Every agent acts on a schemata or structure in a certain space and time. Furthermore, the agents' social activities conversely affect the structure. In literary context, agents refer to both writer and characters in literary work. The result of this study indicates that the phenomenon of ethnocentrism showed through the actions of the characters in the novel is the manifestation of the author's structure. The novel Tenggelamnya Kapal Van der Wijck is a media of communication for Hamka as an agent motivated by his desire for improvements and changes in the structure of Minangkabau culture. This work is also able to change social system that actually constructs Hamka ethnocentrism structure.
\end{abstract}

Keywords: structuration; agent; structure; Anthony Giddens; Tenggelamnya Kapal Van der Wijck

\section{Pendahuluan}

Beragamnya suku yang ada di Indonesia terkadang memberikan dampak yang signifikan dalam urusan suku satu memandang su- ku lainnya. Kecenderungan suku lain merasa lebih dominan dari yang lainnya tidak terhindarkan karena berbagai alasan. Salah satunya 
bisa jadi karena belum terbukanya wawasan tentang kebudayaan lain. Kecenderungan itu bisa jadi bersifat terus menerus hingga memunculkan pandangan bahwa sebuah kebudayaan atau masyarakat tertentu meremehkan yang lainnya atau yang lebih dikenal sebagai istilah etnosentrisme.

Kondisi sosial masyarakat semacam itulah yang kemudian dapat ditemukan dalam sebuah karya sastra karangan Hamka yang berjudul Tenggelamnya Kapal Van der Wijck. Zainuddin yang menjadi tokoh utama dalam novel ini mendapat perlakuan yang semenamena. Hal tersebut disebabkan ayahnya yang suku Minang menikahi seorang perempuan Bugis sehingga Zainuddin dianggap bukan bagian dari suku tempat ia tinggal, yakni suku Minang. Seperti diketahui bahwa di dalam kesukuan Minang, pengambilan garis keturunan diambil dari silsilah ibu bahkan tercatat sebagai penganut matrilineal terbesar di dunia (Blackwood, 1995:127).

Dalam bukunya Ekstrinsikalitas Sastra Indonesia (2007), Maman S Mahayana, kritikus sastra, beranggapan bahwa penggambaran karakternya sangat menarik dan kemampuan Hamka memunculkan keteganganketegangan tersebut disinyalir karena awalnya novel ini merupakan cerita bersambung dalam majalah Pedoman Masyarakat. Seperti pada umumnya cerita bersambung, kemampuan Hamka memikat hati pembaca menjadi tolok ukur kesuksesan cerita yang akan diterbitkan berikutnya. Novel ini juga menuai sukses dengan sudah tersebarnya ke seluruh
Indonesia dan dicetak lebih dari 80 ribu eksemplar serta beberapa kali naik cetak di negara Malaysia (Mahayana, 2007:168-170).

Menilik kesuksesan novel ini serta adanya kemiripan kondisi sosial yang terdapat dalam novel dan yang melingkungi pengarang, maka dalam menganalisisnya digunakan konsep strukturasi yang diinisiasi oleh Anthony Giddens. Posisi Hamka berdasarkan konsep tersebut adalah sebagai agen dan masyarakat yang melingkungi Hamka merupakan sebuah struktur. Keduanya kemudian membentuk hubungan timbal balik. Berdasarkan latar belakang yang telah dipaparkan, permasalahan yang akan dijawab adalah tindakan dan kesadaran tokoh-tokoh dalam novel Tenggelamnya Kapal Van der Wijck dan peran sistem sosial masyarakat dan dualitas struktur Hamka melalui novel Tenggelamnya Kapal Van der Wijck.

Dalam teori strukturasi, Anthony Giddens memfokuskan kajiannya pada dualitas struktur yang menjelaskan mengenai hubungan timbal balik antara agen dan struktur. Agen adalah orang-orang yang konkret dalam arus kontinu tindakan dan peristiwa di dunia (Priyono, 2002:19). Dengan kata lain, agen merujuk kepada manusia yang merupakan subjek yang memiliki kemampuan untuk melakukan tindakan dan bertindak sesuai dengan kesadaran yang dimilikinya atau memahami tindakan mereka saat mereka melakukannya. Kemampuan reflektif aktor manusia terlibat secara terusmenerus mengiringi rangkaian perilaku seharihari dalam konteks sosial (Giddens, 2010:xxii). 
Agen menurut Giddens mempunyai kemampuan untuk membuat suatu perbedaan di dalam dunia sosial. Agen memiliki kekuasaan atau kemampuan untuk mengubah situasi (Ritzer, 2012:892). Kemampuan agen untuk melakukan tindakan tersebut disebut Giddens sebagai agensi. Agensi mengacu pada kemampuan orang dalam melakukan sesuatu. Agensi berkaitan dengan kejadian-kejadian yang melibatkan individu sebagai pelaku, dalam artian bahwa individu itu bisa bertindak berbeda dalam setiap fase apa pun dalam suatu urutan tindakan tertentu (Giddens, 2010:14). Berdasarkan pemaparan tersebut, agen dapat dipahami sebagai subjek yang memiliki kemampuan untuk bertindak atas kesadaran mereka. Dalam karya sastra, agen merujuk pada pengarang dan tokoh-tokoh di dalam karyanya.

Struktur didefinisikan sebagai aturanaturan dan sumber daya yang memungkinkan adanya praktik-praktik sosial serupa yang dapat dilihat membentang rentang waktu dan ruang dan yang memberi bentuk sistemik pada mereka. Giddens berpendapat bahwa struktur hanya ada di dalam dan melalui kegiatan-kegiatan agen-agen manusia. Struktur bersifat membatasi dan memungkinkan. Struktur-struktur terwujud di dalam jejak-jejak memori yang mengorientasikan perilaku agen-agen manusia yang dapat diketahui (Ritzer, 2012:892-893).

Konsep struktur dapat digunakan secara teknis dan secara lebih umum. Tatkala dipahami sebagai aturan dan sumber daya, struktur terlibat secara langsung dalam reproduksi sistem-sistem sosial dan benar-benar mendasar bagi teori strukturasi. Tatkala digunakan secara longgar, struktur bisa dikatakan mengacu pada sifat-sifat institusional (sifat-sifat struktural) masyarakat (Giddens, 2010:287). Berdasarkan beberapa pengertian tersebut, struktur dapat diartikan sebagai seperangkat aturan-aturan dan norma-norma yang tertanam dalam diri agen yang diwujudkan melalui praktik-praktik para agen dalam sistem sosial. Struktur terbentuk melalui interaksi antarindividu dalam masyarakat. Dalam karya sastra, struktur adalah pengalaman hidup agen (pengarang dan tokoh-tokoh) yang diperoleh dari masyarakat tempat agen berinteraksi satu sama lain.

Gagasan penting tentang strukturasi adalah konsep dualitas struktur. Komposisi antara para agen dan struktur bukanlah dua perangkat fenomena tertentu yang saling terpisah, atau sebuah dualisme, melainkan mewakili sebuah dualitas. Menurut gagasan dari dualitas struktur, kelengkapan-kelengkapan struktural dari sistem-sistem sosial adalah sarana sekaligus hasil dari praktik-praktik yang terorganisasi secara rutin (Giddens, 2010:40). Berdasarkan pengertian tersebut, dualitas struktur menekankan hubungan timbal balik antara agen dan struktur. Struktur merupakan pedoman seorang agen dalam bertindak dan agen memiliki kekuasaan untuk melakukan tindakan yang dapat berpengaruh pada perubahan struktur.

Dalam konteks sastra, karya sastra merupa- 
kan representasi struktur agen (pengarang) sekaligus proses komunikasi untuk mengungkapkan pendapat agen terhadap apa yang terjadi di sekitarnya. Karya sastra sebagai sarana agen dalam melakukan praktik sosial bertujuan untuk memengaruhi struktur. Begitu pula dengan tokoh-tokoh dalam karya sebagai agen yang bertindak berdasarkan struktur dan tindakannya tersebut akan kembali memengaruhi struktur. Dengan kata lain, agen dan struktur saling memengaruhi. Tindakan agen dipengaruhi oleh struktur yang membentuknya dan ia pun memiliki kemampuan untuk memengaruhi struktur melalui tindakannya.

Dalam teori strukturasi, tindakan agen didasari oleh 3 jenis kesadaran. Pertama, kesadaran diskursif mengacu pada kapasitas agen untuk merefleksikan dan memberikan penjelasan verbal atas tindakannya (Priyono, 2002:28). Kedua, kesadaran praktis meliputi tindakan-tindakan yang diterima begitu saja oleh para aktor, tanpa mampu mengungkapkan dengan kata-kata apa yang sedang mereka lakukan (Giddens, 2010:76). Kesadaran praktis menunjuk pada gugus pengetahuan praktis yang tidak selalu bisa diurai. Melalui gugus pengetahuan praktis ini, kita tahu bagaimana melangsungkan hidup sehari-hari tanpa harus mempertanyakan terus-menerus apa yang terjadi atau yang mesti dilakukan (Priyono, 2002:29). Ketiga, motivasi tak sadar menyangkut keinginan atau kebutuhan yang berpotensi mengarahkan tindakan (Priyono, 2002:8). Motivasi tidak sadar merupakan satu unsur penting dalam perilaku manusia karena berhubungan dengan motif dan dorongan tak sadar subjek dalam bertindak.

Sehubungan dengan penjelasan di atas, kesadaran diskursif merupakan kemampuan agen untuk menuangkan kejadian yang ada di sekitarnya ke dalam sebuah karya sastra melalui deksripsi secara verbal (tulisan) yang dilakukan pengarang. Sementara itu, kesadaran diskursif tokoh-tokoh dalam karya dapat dilihat melalui narasi serta dialog mereka. Sementara itu, pemahaman mengenai kesadaran praktis dan motivasi tak sadar agen (penulis) dapat diketahui melalui interpretasi atas latar belakang penulisan karya. Kemudian, pemahaman terhadap kesadaran praktis dan motivasi tak sadar tokoh-tokoh diperoleh melalui interpretasi terhadap latar belakang tokoh-tokoh dalam bertindak.

Dalam penelitian ini, penulis menggunakan metode penelitian yang terdiri atas metode pengumpulan dan analisis data. Pengumpulan data dimulai dengan membaca keseluruhan novel secara kritis, kemudian menentukan tindakan dan kesadaran agen yang terdapat di dalam novel. Untuk variabel pertama, peneliti berfokus pada satuan tindakan dan kesadaran masyarakat Minangkabau, Zainuddin, dan Hayati yang dikemukakan dalam teks. Sementara itu, variabel sistem sosial dan dualitas struktur Hamka diperoleh melalui penelusuran kondisi sosial historis yang melingkupinya. Selanjutnya, pada bagian analisis data, peneliti mengidentifikasi kesadaran praktis, diskursif, 
dan motivasi tak sadar penulis melalui tokohtokoh dalam novel. Sistem sosial masyarakat dan dualitas struktur Hamka diidentifikasi dengan melihat hubungan timbal balik yang terbentuk antara struktur Minang dan Hamka sebagai agen. Cara menentukan hubungan tersebut adalah sebagai berikut. Pertama, dengan menguraikan representasi sistem sosial Minangkabau dalam novel Tenggelamnya Kapal Van der Wijck. Kedua, memaparkan fakta sosial-budaya Minangkabau setelah novel diterbitkan. Hal ini menunjukkan pengaruh tindakan agen dalam penciptaan karya terhadap strukturnya.

\section{Tindakan dan Kesadaran Tokoh-Tokoh dalam Novel Tenggelamnya Kapal Van der Wijck}

Kehadiran agen dan tindakannya dalam novel tak dapat dipisahkan dari peran Hamka selaku penulis yang bertindak sebagai pengendali cerita. Penelusuran terhadap struktur dan agen-agen dalam novel merupakan langkah awal untuk mengidentifikasi seperangkat ide, hukum, norma, aturan, dan pengalaman yang tertanam dalam diri Hamka sebagai agen yang kemudian termanifestasikan dalam dunia imajinernya. Tokohtokoh dalam novel juga merupakan agenagen yang saling berinteraksi dalam sebuah sistem sosial. Tindakan agen dipengaruhi oleh struktur tertentu. Para agen melakukan praktik-praktik sosial yang berulang dalam ruang dan waktu berbeda sehingga pada akhirnya memengaruhi struktur itu kembali.

\section{Tindakan dan Kesadaran Masyarakat Minangkabau}

Masyarakat Minangkabau sebagaimana yang dikemukakan dalam novel merupakan masyarakat yang senantiasa mendahulukan adat istiadatnya. Masyarakat tumbuh dengan struktur yang menjunjung tinggi kedudukan perempuan, khususnya ibu. Padang diibaratkan negeri yang berbangsa kepada ibu. Pandangan masyarakat Minangkabau terhadap sosok Zainuddin dapat dilihat dari kutipan berikut.

Tetapi dari sebulan ke sebulan, kegembiraan itu hilang, sebab rupanya yang dikenangkenangnya berlainan dengan yang dihadapinya. Dia tidak beroleh hati yang sebagai hati Mak Base, tidak mendapat kecintaan ayah dan bunda. Bukan orang tak suka kepadanya, tapi berlain kulit dan isi. Jiwanya sendiri mulai merasa, bahwa meskipun dia anak orang Minangkabau tulen, dia masih dipandang orang pendatang, masih dipandang orang jauh, orang bugis, orang Mengkasar (Hamka, 2013: 23).

Dalam struktur budaya Minangkabau, Zainuddin tidak diperlakukan sama seperti anggota keluarga yang lain karena ibu Zainuddin bersuku Bugis sehingga ia bagaikan orang asing. Perilaku masyarakat ini berkaitan dengan tindakan praktis agen dalam konsep Giddens. Tindakan praktis merujuk pada sikap-sikap penolakan agen yang bersifat otomatis dan dianggap wajar terhadap budaya lain. Penolakan ini mengarah kepada pandangan etnosentrisme yang telah menginternalisasi dalam diri agen yang menyebabkan masyarakat Minangkabau memandang bahwa pernikahan sesama suku merupakan sesuatu yang terbaik sehingga terdapat kecenderungan meremehkan suku lain di luar sukunya. Hal ini lebih dipertegas melalui 
kutipan berikut.

Sesudah hampir enam bulan dia tinggal di dusun Batipuh, bilamana dia pergi dudukduduk ke lepau tempat anak-anak-anak muda bersenda gurau, orang bawa pula dia bergurau, tetapi pandangan orang kepadanya bukan pandangan sama rata, hanya ada juga kurangnya (Hamka, 2013:23).

Para pemuda Minangkabau bahkan tumbuh dengan struktur yang sangat lekat dengan pemisahan adat. Meskipun Zainuddin bergabung dan bersenda gurau bersama mereka, tetap jelas baginya bagaimana ia dipandang berbeda. Tindakan para pemuda ini merupakan tindakan praktis yang telah tertanam dalam diri mereka bahwa sosok seperti Zainuddin sampai kapan pun tidak akan pernah menjadi bagian dari suku mereka.

Penolakan masyarakat terhadap Zainuddin semakin memuncak saat mengetahui bahwa Zainuddin dan Hayati menjalin kasih. Struktur masyarakat Minangkabau tidak bisa menerima hal tersebut dan merasa bahwa sikap Zainuddin telah menjatuhkan martabat seorang gadis. Gadis-gadis Minangkabau dengan struktur adat yang tertanam dalam diri mereka melakukan tindakan praktis dengan menggunjing dan memandang Hayati dengan tatapan sinis. Mamak Hayati kemudian bertindak memperingatkan Zainuddin seperti yang terlihat dalam kutipan di bawah ini.

Sekarang saya temui engkau untuk memberi engkau nasihat, lebih baik sebelum perbuatan berkelanjutan, sebelum merusak nama kami dalam negeri, suku sako turun temurun, yang belum lekang di papas dan belum lapuk di hujan, supaya engkau surut (Hamka, 2013:61).

Perilaku mamak tersebut merupakan tindakan diskursif ketika agen menjelaskan secara verbal maksud dari tindakannya. Dalam hal ini, Mamak secara eksplisit menekankan aturan adatnya. Zainuddin dipaksa untuk memutuskan hubungannya dengan Hayati karena hal tersebut dianggap merusak nama baik suku. Tidak seperti Zainuddin, Hayati dipandang perempuan yang jelas silsilah keluarganya, yang bukan sembarang orang, begitu berharga bagi sukunya. Unsur etnosentrisme jelas tergambar dalam penekanan Mamak kepada Zainuddin mengenai tingginya nilai-nilai kesukuan yang dipegang oleh masyarakat. Hal ini tentu merupakan sindirian keras kepada Zainuddin yang dipandang tidak jelas asal usulnya.

Mamak datuk melakukan tindakan diskursif kepada para pemuka adat lainnya mengenai bagaimana kerasnya aturan yang ada di adat mereka. Melalui perundingan yang dilakukan untuk menetapkan calon pendamping Hayati, Mamak-sebutan untuk paman perempuan yang bertanggung jawab sebagai wali-kembali memperjelas mengapa Zainuddin tidak layak diterima. Sikap etnosentrisme lebih ditekankan dalam kutipan berikut.

Meskipun ayahnya orang Batipuh, ibunya bukan orang Minangkabau, mamaknya tidak tentu entah dimana, sukunya tidak ada: tidak ada pepatihnya, tidak ada ketemanggungan-nya. Kalau dia kita terima menjadi suami anak kemenakan kita, ke mana kemenakan kita hendak menjelang iparnya, kemana cucu kita berbako, rumit sekali soal ini (Hamka, 2013:128).

Tindakan datuk melalui otoritas yang dimil- 
ikinya yang tercermin dalam kutipan di atas merupakan proses komunikasi untuk mempertegas kembali nilai-nilai budaya dan mengingatkan para pemuka adat lainnya untuk tetap berpegang teguh dan menjunjung tinggi adat mereka. Hal ini merupakan pemantauan refleksif atas tindakan Mamak sebagai agen untuk tetap menjaga struktur.

\section{Tindakan dan Kesadaran Zainuddin}

Zainuddin merasa diperlakukan tidak adil terhadap struktur yang mengekang. Namun, dia tidak bisa berbuat apa-apa untuk melawan, bahkan mengubah norma yang berlaku di suku Minangkabau. Sikap Zainuddin direpresentasikan melalui kutipan berikut:

Zainuddin telah jemu di Minangkabau, dan dia tidak akan jemu lagi, karena tarikh penghidupan manusia bukan manusia membuatnya, dia hanya menjalani yang tertulis (Hamka, 2013:25).

Kutipan diatas menggambarkan bahwa sebagai seorang yang dipandang orang lain di kampungnya sendiri, Zainuddin hanya bisa menerima struktur yang ada. Di awal keberadaannya di Padang, sebelum menjalin hubungan dengan Hayati, Zainuddin bahkan berusaha untuk menunjukkan budi pekerti yang baik dan sikap terpuji dengan membantu masyarakat sekitar yang sedang bekerja.

Untuk penghindaran muka yang kurang jernih, maka bilamana orang ke sawah, ditolongnya ke sawah, bila orang ke ladang dia pun ikut ke ladang (Hamka, 2013:23).

Tindakannya didorong oleh motivasi tak sadar dalam dirinya bahwa dia telah berdamai dengan struktur dan bisa tetap ber- tahan menghadapinya. Namun, hubungannya dengan Hayati telah menyebabkannya terusir dari kampung. Dia bahkan tetap menerima sikap masyarakat terhadapnya dan mengikuti keinginan mereka untuk meninggalkan Dusun Batipuh dan berpindah ke Padang Panjang. Tindakan Zainuddin yang memilih untuk tetap tinggal di Padang untuk memperdalam ilmu adalah bentuk motivasi tak sadar. Zainuddin yang ingin menunjukkan bahwa dia bisa menjadi seorang yang berguna pada kemudian hari.

Meskipun pada awalnya perlakuan yang diterima Zainuddin dari masyarakat menyebabkannya terpuruk, terutama Hayati yang lebih memilih bertahan pada struktur dan memilih menikahi lelaki pilihan mamak di sukunya. Hal tersebut justru menjadi motivasi tak sadar yang mendorong Zainuddin bertindak. Ia kemudian meninggalkan Sumatra dan menuju ke Jawa. Di Surabaya, ia berhasil menjadi penulis terkenal yang kaya. Hal ini tentu berdampak pada perubahan struktur Zainudin.

Karya-karyanya yang melukiskan kehidupannya tentu merupakan tindakan diskursifnya untuk menunjukkan kepincangan adat dan tradisi yang pernah dialaminya. Hal ini tercermin dari penggalan tulisan Zainuddin sebelum ia menutup usia.

...dan akan tercapai juga kemuliaan bangsaku, persatuan tanah airku. Hilang perasaan perbedaan dan kebencian dan tercapai keadilan dan bahagia (Hamka, 2013:262).

Tindakan Zainuddin menghasilkan karya merupakan proses komunikasi. Melalui tulisannya, ia tentu memiliki harapan yang besar 
untuk menghapus segala bentuk-bentuk perbedaan dan pemisahan yang berlaku dalam sistem tertentu.

\section{Tindakan dan Kesadaran Hayati}

Di awal perjumpaannya dengan Zainuddin, Hayati menunjukkan tindakan diskursif dengan memperingatkan Zainuddin bahwa hubungan mereka tidak akan berjalan dengan mulus karena ketat dan kerasnya struktur adat yang membelenggu. Sikap Hayati ini merupakan pemantauan refleksif atas tindakan. Hal ini bisa dilihat dari kutipan berikut.

Saya ingat kekerasan adat di sini, saya ingat kecenderungan mata orang banyak, akan banyak halangannya jika bercinta-cintaan. Saya takut bahaya dan kesukaran yang akan kita temui, jika jalan ini kita tempuh (Hamka, 2013:57).

Penerimaan Hayati terhadap struktur juga tergambar dari tindakannya yang pada akhirnya menerima ketentuan Mamak untuk menikahkannya dengan Aziz, seorang yang dianggap memenuhi kriteria adat. Hal ini dipaparkan dalam kutipan berikut.

Hayati seorang Gadis yang bercita-cita tinggi, tetapi jiwanya pun tak betah akan mengecewakan hati ninik mamaknya dan kaum kerabatnya dia hanya akan menerima apa tulisan takdir (Hamka, 2013:131).

Tindakan Hayati seperti yang digambarkan di atas merupakan bentuk tindakan menerima struktur yang berlaku di sukunya. Hayati yang besar dan tumbuh dengan struktur pemisahan adat yang keras di sukunya merasa bahwa tindakan melawan adat hanya akan berakhir sia-sia bagi dirinya dan Zainuddin.

Lahir dan besar di suku Minangkabau tentu saja banyak memengaruhi sikap Hayati terhadap etnis lain. Hal ini tentu membentuk pandangan etnosentrisme Hayati sehingga tidak memperjuangkan hubungannya dengan Zainuddin, tetapi lebih memilih Aziz dari suku yang sama di samping pertimbangan lainnya yang sifatnya materialistis. Kuatnya struktur yang membelenggu Hayati sehingga tidak melakukan perlawanan apa pun juga dipaparkan secara rinci dalam penggalan novel berikut.

Tuan kan tahu bahwa saya seorang gadis yang miskin dan tuan pun hidup dalam melarat pula, tak mempunyai persediaan yang cukup untuk menegakkan rumah tangga. Maka lebih baik kita singkirkan perasaan kita, kembali kepada pertimbangan. Lebih baik kita berpisah, dan kita turutkan perjalanan hidup masing-masing menurut timbangan kita, mana yang lebih bermanfaat buat di hari nanti (Hamka, 2013:159).

Kutipan di atas melukiskan tindakan diskursif Hayati menolak Zainuddin disebabkan besarnya pengaruh keluarga dan sahabatnya yang meyakinkannya untuk tidak memilih Zainuddin sebagai suaminya. Penolakan ini tentu dilandasi oleh beberapa pertimbangan terkait asal-usul dan kondisinya yang tidak mapan atau miskin.

\section{Peran Sistem Sosial Masyarakat dan Dua-}

\section{litas Struktur Hamka Melalui Novel}

\section{Tenggelamnya Kapal Van der Wijck}

Pada penjelasan sebelumnya, dapat diketahui bahwa novel ini menekankan pada etnosentrisme. Hal tersebut dapat diidentifikasi 
Poetika : Jurnal Ilmu Sastra

Vol. VII No. 1, Juli 2019 dari tindakan dan kesadaran tokoh-tokoh di dalam novel. Untuk mengetahui alasan dimunculkannya isu etnosentrisme dalam novel tersebut, maka perlu dilihat sistem sosial yang melingkungi pengarang.

\section{Representasi Struktur Hamka dalam Tenggelamnya Kapal Van der Wijck}

Hamka menuangkan struktur yang membentuknya dalam karya sastra. Hal itu dapat dilihat melalui unsur-unsur instrinsik dalam karya sastra yang bisa jadi berupa latar tempat, latar waktu, ataupun tokoh dalam novel ini. Dalam bagian ini, akan dibahas tentang dualitas struktur Hamka yang muncul melalui novel.

Sehingga lama-lama insaflah dia perkataan mak Base seketika dia akan berlayar, bahwa adat orang di Minangkabau lain sekali. Bangsa diambil daripada ibu. Sebab itu, walaupun seorang anak berayah orang Minangkabau, sebab di negeri lain bangsa diambil dari ayah, jika ibunya orang lain, walaupun orang Tapanuli atau Bengkulu yang sedekat-dekatnya, dia dipandang orang lain juga. Malang nasib anak yang demikian, sebab dalam negeri ibunya dia dipandang orang asing, dan dalam negeri ayahnya dia dipandang orang asing pula. (Hamka, 2013)

Dari kutipan di atas, dapat kita ketahui bahwasanya Hamka menggambarkan adat yang terdapat dalam lingkungan sosial tempat dia dilahirkan dan dibesarkan dalam sebuah kondisi ketika Zainuddin mengingat apa yang dikatakan Mak Base bahwa adat Minangkabau berbeda dengan adat umumnya. Jika di tempat lain garis keturunan diambil dari ayah (partrilineal), sedangkan di Minangkabau justru diambil dari keturunan ibu (matrilineal).
Dalam kondisi ini pun dapat dianalisis bahwa munculnya etnosentrisme sudah menjadi konflik pembuka dalam novel. Suku dan asal usul orang tua Zainuddin menjadi penentu dia dianggap orang asing atau tidak. Pandangan tersebut membuat Zainuddin mengalami keterasingan, baik saat di Makassar yang menjadi tanah air ibunya maupun di Padang yang menjadi tanah air ayahnya.

Seorang anak muda yang datang ke kampung, yang lahir dari pada perkawinan sah, dan ibunya bukan pula keturunan sembarang orang, malah Melayu pilihan dari Bugis, dipandang orang lain. Tetapi harta seorang ayah, yang sedianya akan turun kepada anaknya, dirampas, dibagi dengan nama "adat" kepada kemenakannya. Kadang-kadang pula pemberian ayah kepada anaknya semasa dia hidup, diperkarakan, dan didakwa ke muka hakim oleh pihak kemenakan, tidak tercela, bahkan terpandang baik. (Hamka, 2013:68)

Seperti halnya yang telah dijelaskan dalam kondisi sosial masyarakat Minangkabau tentang harta dan warisan, di sini dapat diketahui bahwa Hamka ingin menekankan pada adat pembagian harta dan warisan yang dirasakannya tidak sesuai dengan seharusnya. Jika kita melihat latar belakang Hamka yang juga ulama, pastilah terjadi pergolakan batin karena dalam Islam, istri dan anak merupakan tanggung jawab suami.

Mamak-mamak duduk berapat di kepala rumah yang di hilir, perempuan-perempuan duduk didekat jalan ke dapur, mendengarkan buah mupakat dari jauh. Orang semanda, ya-itu suami dari kemenakan-kemenakan, dari pagi sudah sengaja tidak pulang, sebab "orang" akan musyawarat dalam sukunya, padahal mereka hanya "urang semanda," mengebat tidak erat, memancung tidak putus, lengau di ekor kerbau, debu di atas tunggul, lecah lekat di kaki. Walau 
pun kadang-kadang anaknya sendiri yang akan dipertunangkan atau dikawinkan. Dia hanya kelak akan diberi kata yang telah masak saja. (Hamka, 2013:125-126)

Dalam adat Minangkabau, segala yang menentukan adalah mamak, termasuk juga pernikahan. Saat Hayati akan dijodohkan oleh mamak-mamaknya karena Hayati adalah yatim piatu. Dalam adat Minangkabau, para suami tidak punya hak apa pun untuk ikut serta dalam penentuan pernikahan anaknya. Yang mereka ketahui hanyalah hasil akhir atas musyawarah yang dilakukan mamak-mamak.

Dalam menentukan seorang suami yang ideal, yang menjadi prioritas utama adalah ketinggian derajat suatu golongan dalam adat Minangkabau. Mereka menganggap asing dan menolak mereka yang tidak berasal dari suku Minangkabau beserta keturunannya. Sikap meremehkan kebudayaan suku lain melalui proses ketika penghulu dan pemuka adat Minangkabau selalu menjadikan kesukuannya menjadi patokan utama dalam memandang sebuah permasalahan, seperti dalam kutipan berikut ini.

“....Meski pun ayahnya orang Batipuh, ibunya bukan orang Minangkabau, mamaknya tidak tentu entah di mana, sukunya tidak ada Tidak ada Perpatihnya, tidak ada Ketemanggungannya. Kalau dia kata terima menjadisuami anak kemenakan kita, ke mana kemenakan kita hendak menjelang iparnya, ke mana cucukita berbako, rumit sekali soal ini."(Hamka, 2013:128)

"Itu betul, tetapi tidak ada yang melebihi Minangkabau. Tatkala masa dahulunya, sampai ke Aceh tiga segi, sampai Teratak Air Hitam, sampai ke Bugis ke Mengkasar, di bawah perintah Minangkabau semuanya. Membayar hak dacing pengeluaran, ubur-ubur gantung kemudi, ke dalam alam Minangkabau." (Hamka, 2013:129)

Tidak hanya kesukuan, ketinggian derajat kemuliaan bangsa dan kekayaan juga menjadi hal utama dalam memilih suami. Seperti yang ada dalam kutipan berikut.

“...Namanya Aziz, anak dari St. Mantari, seorang yang termasyhur dan berpangkat semasa hidupnya. Karena menurut adat yang biasa, tentu kita kaji lebih dahulu, hereng dengan gendeng, ribut nan mendingin, renggas nan melanting, dikaji adat dan lembaga, yang tidak lapuk di hujan, nan tidak lekang di panas, jalan raya titian batu, nan sebaris tidak hilang nan sehuruf tidak lupa." (Hamka, 2013:126)

Maka mulailah menjawab satu-persatu di antara yang hadir, memperkatakan asal dan usul, mengaji hindu dan suku, menyelidiki dari manakah asal usul Aziz, adakah dia peranakan orang dari luar Minangkabau, karena maklumlah di kota Padang Panjang orang telah banyak bercampur gaul. (Hamka, 2013:126)

Lalu diuji pula kekayaannya, hartanya yang berbatang, sawahnya yang berbintalak, dikaji sasap jerami, pendam pekuburan, bekas-bekas harta yang telah dibagi dan yang belum dibagi di negerinya... Karena memang nyata bahwa dia orang asal, patut dijemput kita jemput, patut dipanggil kita panggil. (Hamka, 2013:126-127)

...Yang membayar wang jemputan ialah pihak yang perempuan, menurut derajat kemuliaan bangsa si laki-laki pula. (Hamka, 2013:127)

Latar belakang sosial masyarakat Hamka sebagai salah satu putra Minangkabau terlihat jelas sekali, hingga uang jemputan yang menjadi ciri khas Minangkabau pun tidak lepas dari novel ini. Uang ini yang membayar adalah pihak perempuan, yakni Mamak Hayati. Oleh karenanya, mereka merasa berhak menentukan nasib kemenakannya itu. Tidak hanya paham etnosentrisme yang ditekankan oleh para 
pemangku adat, tetapi juga materialisme yang menggunakan nama adat untuk memperkaya kesukuan mereka sendiri.

\section{Sistem Sosial Masyarakat Minangkabau}

\section{dan Dualitas Struktur Hamka}

Dengan menyajikan kondisi masyarakat pada saat dan tempat dia hidup, kita dapat menganalisis struktur yang dimiliki pengarang dalam penciptaan karya sastranya. Beragamnya suku yang ada di Indonesia terkadang memberikan dampak yang signifikan dalam urusan hubungan antarsuku. Kecenderungan suku lain merasa lebih dominan dari yang lainnya tidak terhindarkan karena berbagai alasan. Salah satunya bisa jadi karena belum terbukanya wawasan tentang kebudayaan lain. Kecenderungan itu bisa jadi bersifat terus-menerus hingga memunculkan pandangan bahwa sebuah kebudayaan atau masyarakat tertentu meremehkan yang lainnya atau yang lebih dikenal sebagai istilah etnosentrisme.

Di dalam KBBI, etnosentrisme didefinisikan sebagai sikap atau pandangan yang berpangkal pada masyarakat dan kebudayaan sendiri. Bia-sanya disertai dengan sikap dan pandangan yang meremehkan masyarakat dan kebudayaan lain. Tampaknya, kondisi etnosentrisme Indonesia yang seperti itu dapat ditangkap dalam novel karangan Hamka berjudul Tenggelamnya Kapal Van der Wijck ini. Dikatakan demikian karena terdapat sebuah kondisi sosial ketika suatu kebudayaan yang merasa lebih baik dari kebudayaan lainnya sehingga timbul perlakuan- perlakuan yang tidak seharusnya kepada individu dengan budaya atau berasal dari suku yang berbeda.

Dalam perspektif strukturasi Giddens, novel ini merupakan salah satu bentuk karya di mana Hamka-sebagai agen sebuah struktur sekaligus pengarang-melakukan proses komunikasi melalui karya sastra untuk mengungkapkan bahwa ada gejala etnosentrisme dalam budaya tempat dia mendapatkan struktur yang membentuknya. Hamka adalah salah satu pemuka agama Islam asal Minangkabau. Menilik keadaan masyarakat tempat Hamka lahir dan dibesarkan, pastilah hal itu merujuk pada adat Minangkabau yang menggunakan sistem kekerabatan matrilineal.

Dengan menyajikan kondisi masyarakat pada saat dan tempat dia hidup, dapat menganalisis struktur yang dimiliki pengarang dalam penciptaan karya sastranya. Oleh karenanya, harus diketahui terlebih dahulu budaya dan adat Minangkabau agar dapat diidentifikasi kondisi sosial masyarakatnya serta struktur yang membentuk pengarang. Matrilineal didefinisikan KBBI sebagai berbagai hal mengenai hubungan keturunan melalui garis kerabat perempuan. Dengan demikian dapat diketahui bahwa ga-ris keturunan diambil dari pihak ibu. Tentu saja pengambilan garis keturunan semacam ini memiliki perbedaan di berbagai bidang terutama jika pada umumnya garis keturunan diambil dari pihak ayah (patrilineal).

Pada bidang kepemilikan harta dan warisan (dalam adat Minangkabau disebut pusako), misalnya, warisan diturunkan kepada kepona- 
kan (Minang: kemenakan) perempuan baik yang warisan yang berupa gelar atau harta (Minang: sako dan pusako). Sementara itu, untuk keponakan laki-laki, mereka mendapat hak mengusahakan (Navis, 1984:158-159). Namun sejak tahun 1963 terjadi perubahan ketika jenis harta dibagi menjadi dua. Hal ini diputuskan dalam Rapat Empat Djinis orang Alam Minangkabau. Ada pun pembagiannya adalah harta pusaka tinggi (warisan turun temurun) dan harta pusaka rendah (harta pencarian) (Hamka, 1963:7-8).

Dalam buku sejarahnya yang berjudul Adat Minangkabau Menghadapi Revolusi, Hamka juga menjelaskan secara gamblang bahwasanya yang menjadi puncak pemegang keputusan tertinggi dalam rumah adalah nenek dari pihak perempuan. Seorang suami tidak wajib memberi nafkah kepada anak istrinya, tetapi justru memenuhi kebutuhan keponakannya. Tidak hanya urusan harta, tetapi berbagai urusan lainnya juga merupakan tanggung jawab saudara laki-laki dari pihak ibu (Minang: mamak). Seperti halnya urusan pernikahan (Hamka, 1963:33-34).

Pernikahan dalam adat Minangkabau diatur oleh mamak dari pihak perempuan sehingga semua urusan mulai dari menyalang mata (melihat laki-laki yang cocok untuk menjadi suami), meminang, batimbang tando (hari pertunangan), sampai hari pernikahan menjadi tanggung jawab mamak. Termasuk pula keperluan-keperluan di dalam proses yang sedemi-kian panjang itu, ketika keperluan itu berupa uang jemputan yang diberikan kepada ibu pengantin laki-laki dan uang dapur (biaya yang diminta untuk melangsungkan pernikahan). Semakin tinggi gelar tuturan mempelai laki-laki (misal: sidi, bagindo, dan sutan), semakin besar pula uang jemputan yang diperlukan. Karena masyarakat Minangkabau sangat "tergila-gila" akan gelar, maka berapa pun akan dipenuhi agar mereka bisa mendapatkan gelar tersebut (Navis, 1984:200-201).

Selain itu, ada juga yang disebut Penghulu dalam adat Minangkabau. Umumnya, penghulu yang dimaksud adalah orang yang menikahkan mempelai pria dan wanita, tetapi dalam adat Minangkabau tidak demikian. Penghulu adalah pemimpin suku, biasanya bergelar Datuk. Mamak dalam fungsi sosialnya juga merupakan pemimpin sehingga pemimpin golongan pun diambil menurut sistem matrilineal (Navis, 1984:130-135).

Hamka menjelaskan bahwa ikut campurnya Belanda dengan selalu memenangkan hukum adat yang dijelaskan di atas juga semakin memperkuat eksistensi hukum adat tersebut (Hamka, 1963:37). Para Penghulu pun merupakan orang kepercayaan Belanda yang bertugas memungut rodi dan belasting (pajak) (Hamka, 1963:48). Karena diterbitkan oleh penerbit swasta, maka novel ini kemungkinan tidak terikat dengan berbagai kepen-tingan negara untuk mengatur rakyatnya.

Kondisi masyarakat yang sedemikian rupa digunakan oleh Hamka untuk menggambarkan latar belakang sosial masyarakat dalam novel ini. Tentu saja, pemaparan terkait gejala etnosentrisme tersebut dapat dilihat pada pem- 
bahasan sebelumnya tentang tindakan dan kesadaran tokoh-tokoh serta representasi struktur Hamka yang terdapat di dalam novel. Selanjutnya dapat diidentifikasi bahwa karya Hamka ini memberikan pengaruh terhadap struktur etnosentrisme yang mengkonstruksinya.

Saat Indonesia telah merdeka tahun 1945, eksistensi Belanda pun hilang dan berganti dengan kepemimpinan Soekarno. Semangat bersatu dan berjuang bersama membubung tinggi guna memajukan negeri. Pada saat itu, pemberantasan buta huruf menjadi fokus utama pemerintah agar semakin terbukanya pengetahuan yang akan didapat oleh putraputri bangsa. Sementara itu, di dalam adat Minangkabau, buta huruf dijadikan pertahanan bagi para pemuka adat untuk memperkokoh sistem adat yang mereka jalankan (Hamka, 1963:58).

Terbukanya wawasan dan pengetahuan melalui membaca membuat adat berubah dan mulai ditinggalkan. Dulunya, mereka yang bersekolah hanyalah mereka yang "terpilih", tetapi zamannya telah berubah, kewajiban bersekolah pun tidak pilih-pilih. Karena seperti yang termaktub dalam pembukaan UUD 1945, mencerdaskan kehidupan bangsa merupakan tugas negara. Selain itu, orang Minangkabau harus menyadari bahwa tidak hanya mereka saja negeri yang berkebudayaan, tetapi juga ada kebudayaan lain yang juga tinggi adatnya sepertihalnya Jawa, Bugis, Banjar, Melayu, Aceh, dll (Hamka, 1963:58).
Dengan kejadian tersebut, karya sastra pun akhirnya dibaca semakin luas dan ide-ide pengarang dinilai lebih dari sekadar kisah penghibur belaka. Etnosentrisme yang ditonjolkan dalam novel ini dan yang juga dipaparkan berdasarkan keadaan sosial masyarakat juga menjadi pekerjaan rumah penting bagi para pemerintah yang gencar menggiatkan semangat nasionalisme dan patriotisme.

Para pemikir negeri dari tanah Minangkabau yang telah mengenyam dunia pendidikan dan merantau ke beberapa daerah di negeri ini pun akhirnya saling bertukar pikiran dan menghasilkan musyawarah yang disebut dengan Rapat Empat Djinis pada tanggal 2-4 Mei 1953. Musyawarah ini dipimpin oleh Hadji Mansur Daud (Datuk Palimo Kajo) dan dihadiri oleh Hamka serta Alm. Bapak Hadji Agus Salim, serta para penghulu ninikmamak, ulama, cendekiawan, dan mantidubalang (hulubalang). Itulah alasannya disebut dengan Rapat Empat Djinis karena dihadiri oleh 4 elemen penting dalam adat Minangkabau. Adapun kesepakatan yang didapatkan adalah sebagai berikut:

Dengan ini, saja Dr. Hadji Abdulmalik Karim Amrullah (HAMKA), gelar Datuk Indomo, memberikan kesaksian bahwa saja turut hadir dan turut mempertimbangkan dan turut memutuskan didalam Rapat Empat Djinis orang Alam Minangkabau jang bersidang di Bukittinggi (Luhak Agam) pada tanggal 2 sampai 4 Mei 1953.

Bahwa rapat itu dengan kesepakatan bersama dipimpin oleh Hadji Mansur Daud gelar Datuk Palimo Kajo.

Bahwa turut hadir djuga tjerdik-pandai Alam Minangkabau jang terkenal Almarhum Bapak Hadji Agus Salim dan turut pula memutuskan; 
jaitu:

a. Bahwa harta pusaka (pusaka tinggi) jang telah didapati turun temurun dari nenekmojang menurut garis keibuan diturunkan menurut sepandjang adat.

Bahwa harta pentjaharian menurut adat bernama "Pusaka Rendah" diturunkan peraturan sjara;

b. Bahwa keputusan kerapatan itu adalah SAH menurut peraturan Adat Minangkabau, sebab dihadiri oleh orang empat djinis, jaitu pengulu ninik-mamak, alim ulama,tjerdikpandai dan manti dubalang jang datang sebagai utusan dari seluruh Alam Minangkabau, sedjak dari Riak nan berdabur, Siluluk Punai Mati, Sirangkak nan badangkung, Buaja Putih Daguk, Teratak Air-Hitam, Sikilang Air-Bangis dan Durian di Tengkuk Radja dan telah dihimbaukan dilabuh nan golong di pasar nan ramai, jang ketjil tahu jang gedang pandai, sehingga murai tak berkitjau dan ajam tidak berkokok lagi, dan dihadiri pula oleh Kepala Daerah Propinsi Sumatra Tengah ketika itu Jth.Gubernur Sumatra Tengah R. Ruslan Muljohardjo dan wakil dari Kementerian Agama R.H. Djunaidi :

Bahwa inilah jang dinamai ADAT ISTIADAT berdasar kepada pepatah "BULAT KATA DIMUPAKATKAN" sehingga kalau dilanggar akan dikutuk Kalamullah.

Demikianlah keterangan ini saja berikan dengan kesadaran kepada kedudukan saja sebagai salah seorang ninik-mamak dan alimulama di Minangkabau;

Dr. H. Abdulmalik Karim Amrullah gelar Datuk Indomo;

Kebajoran-Baru, 5 April 1963 (Hamka, 1963: 7-8)

Inilah yang disebut dengan dualitas struktur ketika Hamka melakukan tindakan berkarya dalam sebuah struktur yang membentuknya, sedangkan di saat yang sama, karya tersebut juga mempunyai pengaruh terhadap struktur etnosentrisme yang dimiliki pengarang. Tindakannya menuangkan perbedaan etnis dan etnosentrisme untuk memunculkan tragedi serta ketegangan dalam novelnya menghasilkan penerimaan yang positif dan mampu memberikan perubahan pada masyarakat Minangkabau secara luas.

Melalui musyawarah Rapat Empat Djinis tersebut, kita dapat mengetahui bahwa etnosentrisme yang menjadi fokus utama dalam novel ini menjadikan agen-agen lain di masyarakat melakukan monitoring terhadap tindakan yang dilakukan Hamka. Salah satu monitoring yang dilakukan adalah melakukan evaluasi terhadap sistem adat Minangkabau dan dihasilkannya perubahan pada sistem masyarakat tersebut. Dalam perspektif strukturasi Giddens, hal ini merupakan sebuah kondisi di mana tujuan agen tercapai dan menghasilkan perubahan yang mampu mengubah sistem sosial masyarakat yang membentuk struktur pengarang.

\section{Kesimpulan}

Berdasarkan penelitian terhadap etnosentrisme dalam novel Tenggelamnya Kapal Van der Wijck karya Hamka melalui perspektif Strukturasi Giddens dapat ditarik sebuah kesimpulan bahwa isu etnosentrisme masyarakat Minangkabau yang direpresentasikan oleh Hamka selaku agen melalui novelnya merupakan suatu upaya komunikasi kepada masyarakat. Hamka secara aktif melakukan monitoring terhadap struktur Minangkabau, sehingga ia bertindak melalui kesadaran praktisnya menulis novel. Secara diskursif, ia menuangkan pengalaman dan seperangkat pengetahuannya terkait kondisi sosial-budaya Minang dalam novelnya. Hal ini sekaligus menjelaskan moti- 
vasi tak sadar Hamka yang menginginkan perbaikan terhadap permasalahan etnosentrisme serta sistem kekerabatan matrilineal dalam adat Minangkabau. Perubahan struktur ke arah perbaikan melalui upaya kritisnya menandakan keberhasilan Hamka selaku agen yang hidup dalam budaya Minang.

\section{Daftar Pustaka}

Blackwood, Evelyn; Ong, Aihwa; Peletz, Michael G. 1995. Senior Women, Model Mothers, and Dutiful Wives: Managing Gender Contradictions in a Minangkabau Village dalam buku Bewitching Women, Pious Men: Gender and Body Politics in Southeast Asia. California: University of California Press.

Giddens, Anthony. 2010. Teori Strukturasi. Yogyakarta: Pustaka Pelajar.
Hamka. 1963. Adat Minangkabau Menghadapi Revolusi. Jakarta: Firma Tekad. 2008. Menggebrak Tradisi. Tempo (Jakarta). Diarsipkan dari versi asli tanggal 4 Juni2012. Diakses tanggal 26 Oktober 2016.

. 2013. Tenggelamnya Kapan Van der Wijck. Jakarta Timur: Balai Pustaka.

Mahayana, Maman. S. 2007. Ekstrinsikalitas Sastra Indonesia. Jakarta: Raja Grafindo Persada.

Navis, A. Akbar. 1984. Alam Terkembang Jadi Guru: Adat dan Kebudayaan Minangkabau. Jakarta: Temprint.

Priyono, Herry. 2002. Anthony Giddens: Suatu Pengantar. Bogor: Grafika Mardi Yuana.

Ritzer, George. 2012. Teori Sosiologi: Dari Sosiologi Klasik Sampai Perkembangan Terakhir PostModern. Yogyakarta: Pustaka Pelajar.

\section{Daftar Laman}

Kamus Besar Bahasa Indonesia. https:// kbbi.web.id/matrilineal. Diakses pada tanggal 21 April 2019. 